Kemudi: Jurnal IImu Pemerintahan| 199

Volume 05 Nomor 02 Februari 2021

2622-9633 (Online)

Open Access at: https://ojs.umrah.ac.id/index.php/kemudi DOI: https://doi.org/10.31629/kemudi.v5i02.2442

\title{
Efektivitas Alokasi Dana Desa Dalam Meningkatkan Pembangunan Di Desa Pulokalapa Kecamatan Lemahabang Kabupaten Karawang
}

\author{
Rio Nardianto \\ Program Studi IImu Pemerintahan, Fakultas IImu Sosial dan IImu Politik \\ Universitas Singaperbangsa Karawang \\ rio.nardianto@fisip.unsika.ac.id \\ Gili Argenti \\ Dosen Ilmu Pemerintahan, Fakultas Ilmu Sosial dan Ilmu Politik \\ Universitas Singaperbangsa Karawang \\ gili.argenti@fisip.unsika.ac.id \\ Evi Priyanti \\ Dosen Ilmu Pemerintahan, Fakultas Ilmu Sosial dan Ilmu Politik \\ Universitas Singaperbangsa Karawang \\ evi.priyanti@fisip.unsika.ac.id
}

\begin{abstract}
ABSTRAK
Penelitian ini bertujuan untuk mengetahui Efektivitas Alokasi Dana Desa Dalam Pembangunan Di Desa Pulokalapa Kecamatan Lemahabang Kabupaten Karawang. Metode penelitian yang digunakan dalam penelitian ini adalah metode deskriptif dengan pendekatan kualititatif. Teknik pengumpulan data yang dilakukan penulis dalam penelitian ini adalah studi kepustakaan dan studi lapangan (observasi, wawancara dan dokumentasi). Data yang digunakan dalam penelitian ini adalah data primer dan data sekunder dengan subjek penelitian yang terdiri dari Pemerintah Desa, Badan Permusyawaratan Desa dan Masyarakat Desa Pulokalapa. Hasil penelitian menunjukan bahwa Efektivitas Alokasi Dana Desa Dalam Meningkatkan Pembangunan Di Desa Pulokalapa Kecamatan Lemahabang Kabupaten Karawang, dimana ada empat tahap yakni adaptasi, efisiensi, pengembangan dan kepuasan. Secara administrasi keempat tahap tersebut dapat terselesaikan dengan baik. Namun belum bisa dikatakan efektivitas karena kurangnya transparansi informasi kepada masyarakat dan kurang melibatkan masyarakat dalam pelaksanaan pembangunan.
\end{abstract}

\section{Kata Kunci: Efektivitas, Alokasi Dana Desa, Pembangunan}

\section{Pendahuluan}

Pemberian otonomi daerah seluas luasnya berarti pemberian kewenangan dan keleluasaan (diskresi) kepada daerah untuk mengelola dan memanfaatkan sumberdaya daerah secara optimal. Agar tidak terjadi penyimpangan dan penyelewengan, pemberian wewenang dan keleluasaan yang luas tersebut harus diikuti dengan pengawasan yang kuat. Meskipun titik berat otonomi diletakkan pada tingkat Kabupaten/Kota, namun secara esensi sebenarnya kemandirian tersebut harus dimulai dari level pemerintahan ditingkat paling bawah, yaitu Desa. Selama ini, pembangunan desa masih banyak bergantung dari pendapatan asli desa dan swadaya masyarakat yang jumlah maupun sifatnya tidak dapat diprediksi. 
200 | Rio Nardianto, Gili Argenti, Evi Priyanti. Efektivitas Alokasi Dana...

Desa adalah salah satu bentuk kuno dari kehidupan bersama sebanyak beberapa ribu orang, hampir semuanya saling mengenal, kebanyakan yang termasuk didalamnya hidup dari pertanian, perikanan, dan usaha-usaha yang dapat dipengaruhi oleh hukum dan kehendak alam lainnya, dan dalam tempat tinggal itu terdapat banyak ikatan-ikatan keluarga yang rapat, ketaatan, dan kaidah-kaidah sosial. Sunardjo (dalam Julianto, 2017:483) menyatakan bahwa Desa adalah suatu kesatuan masyarakat hukum berdasarkan adat dan hukum adat yang menetap dalam suatu wilayah tertentu batasbatasnya, memiliki ikatan lahir batin yang sangat kuat, baik karena keturunan maupun kesamaan kepentingan politik, ekonomi, sosial, dan keamanan, memiliki susunan pengurus yang dipilih bersama, memiliki kekayaan dalam jumlah tertentu dan berhak menyelenggarakan rumah tangganya sendiri.

Dengan adanya Undang-undang Nomor 6 Tahun 2014 tentang Desa telah membawa perubahan yang mendasar bagi kedudukan dan relasi desa dengan daerah dan pemerintahan yang baik dari aspek kewenangan, perencanaan, pembangunan, keuangan dan demokrasi desa. Kedudukan desa dalam Undang-undang desa kini lebih kuat. Dalam penjelasan Undang-undang Nomor 6 Tahun 2014 tersebut menyatakan bahwa Desa adalah kesatuan masyarakat hukum yang memiliki batas wilayah yang berwenang untuk mengatur dan mengurus urusan pemerintahan, kepentingan masyarakat setempat berdasarkan prakarsa masyarakat, hak asal usul, dan/atau hak tradisional yang diakui dan dihormati dalam sistem pemerintahan Negara Kesatuan Republik Indonesia.

Desa merupakan suatu kegiatan pemerintah desa, lebih jelasnya pemikiran ini didasarkan bahwa penyelenggaraan tata kelola desa (disingkat penyelenggaraan desa), atau yang dikenal selama ini sebagai "Pemerintahan Desa". Kepala Desa adalah pelaksana kebijakan sedangkan Badan Permusyawaratan Desa dan lembaga pembuat dan pengawas kebijakan (Peraturan Desa). Pengelolaan keuangan desa menjadi wewenang desa yang dijabarkan dalam Peraturan Desa (Perdes) tentang anggaran dan pendapatan belanja desa (APB Desa). Dengan sumber pendapatan yang berasal dari pendapatan asli desa seperti hasil usaha desa, hasil swadaya dan partisipasi, hasil gotong royong dan lain-lain pendapatan asli desa yang sah.

Dalam Undang-undang Nomor 6 Tahun 2014 tentang desa menyebutkan bahwa bagian dari dana perimbangan yang diterima Pemerintah Daerah Kabupaten/Kota paling sedikit $10 \%$ (sepuluh perseratus) setelah dikurangi Dana Alokasi Khusus yang selanjutnya disebut Alokasi Dana Desa. Dengan bergulirnya dana-dana perimbangan melalui Alokasi Dana Desa (ADD) harus menjadikan desa benar-benar sejahtera. Untuk persoalan Alokasi Dana Desa (ADD) saja, meski telah diwajibkan untuk dianggarkan di pos APBD, namun lebih banyak daerah yang belum melakukannya Untuk itu, seharusnya proses transformasi kearah pemberdayaan desa terus dilaksanakan dan didorong semua 
elemen untuk menuju Otonomi Desa. Apabila melihat jumlah anggaran yang diberikan kepada desa melalui Alokasi Dana Desa. Besarnya Alokasi Dana Desa pada pelaksanaanya masih memprioritaskan oprasional Desa dibandingkan pembangunan fisik, bisa kita lihat dari tabel di bawah ini.

\section{Tabel 1}

\section{Alokasi Dana Desa (ADD) Kegiatan Pembangunan Fisik Desa Pulokalapa Kecamatan Lemahabang Kabupaten Karawang Tahun 2018}

\begin{tabular}{|l|l|l|}
\hline Siltap kades dan perangkat & Rp 241.200 .000 & ADD \\
\hline Tunjangan BPD & Rp 81.000 .000 & ADD \\
\hline Oprasional RT/RW & Rp 82.800 .000 & ADD \\
\hline Gaji linmas & Rp 6.000 .000 & ADD \\
\hline Oprasional pemerintahan & Rp 17.483 .310 & ADD \\
\hline Oprasional BPD & Rp 9.414 .090 & ADD \\
\hline Oprasional LPM & Rp 5.500 .000 & ADD \\
\hline Oprasional PKK & Rp 7.500.000 & ADD \\
\hline Oprasional karangtaruna & Rp 2.000.000 & ADD \\
\hline Oprasional PMT & Rp 690.150 & ADD \\
\hline Pembangunan fisik musolah & Rp 47.070.450 & ADD \\
\hline & Jumlah & Rp 500.658.000 \\
\hline
\end{tabular}

Sumber: Data APBDesa Tahun 2018

Berdasarkan tabel 1 kondisi anggaran alokasi dana desa menurut data APBDesa menunjukan adanya jumlah anggaran tahun 2018, total alokasi dana desa pulokalapa yaitu sebesar Rp 500.658.000 belum memprioritaskan pembangunan, bisa dilihat tabel di atas dengan besarnya anggaran alokasi dana desa pembangunan yang diwujudkan hanya pembangunan musolah dengan biaya Rp 47.070 .450 sedangkan sisanya Rp 453.587.550 untuk peralatan desa dan gaji pegawai desa.

Berdasarkan hasil observasi, peneliti menemukan permasalahan pengelolaan Alokasi Dana Desa yang pertama, besarnya Alokasi Dana Desa pada pelaksanaanya masih memprioritaskan oprasional Desa dibandingkan pembangunan fisik, yang kedua rendahnya sumber daya manusia, baik pengelolaan aset Desa maupun sumber daya manusia dalam menunjang kemandirian untuk membiayai rumah tangganya sendiri dan yang ketiga rendahnya partisipasi, swadaya dan gotong royong masyarakat dalam pelaksanaan Alokasi Dana tersebut dan kurangnya pemamahan masyarakat terhadap kebijakan Alokasi Dana Desa, terutama dalam perencanaan pembangunan di Desa pulokalapa masih belum sepenuhnya masyarakat mengetahui tentang perencanaan pengelolaan alokasi dana desa dalam peruntukannya untuk apa saja, salah satunya yaitu pembangunan fisik yang bersumber dari dana alokasi dana desa.

Alokasi dana desa bisa dicairkan tiap tahun, salah satunya pada tahun 2018 anggaran alokasi dana desa yang diterima sebesar Rp 500.658.000. Informasi untuk perencanaan pengelolaan alokasi dana desa dalam pembangunan tahun anggaran 2018 disalurkan untuk pembangunan tempat ibadah, sedangkan sisanya untuk mengganti peralatan kantor desa yang menurut peneliti masih layak untuk digunakan dan masih 
202 | Rio Nardianto, Gili Argenti, Evi Priyanti. Efektivitas Alokasi Dana...

berfungsi dengan baik. Karena belum transfaran anggaran yang diterima pemerintah Desa maka masyarakat tidak pernah tahu anggaran yang diterima desa sehingga masyarakat tidak bisa mengontrol kemana arah dan tujuan dana desa yang telah direncanakan pemerintah desa. Sehingga anggaran yang telah diterima kurang tepat sasaran yang diakibatkan keserakahaan desa sedangkan masyarakat yang dirugikan.

Alokasi Dana Desa berperan penting dan menjadi kunci utama keberhasilan otonomi desa. Yustika (dalam Agustoni, 2019:3) Efektifitas dan Efisiensi penyaluran Alokasi Dana Desa (ADD) dari Pemerintah Kabupaten/Kota ke Pemerintah Desa serta bagaimana pemanfaatan dana tersebut menjadi sangat penting, karena keduanya merupakan parameter paling sederhana bagi keberhasilan desentralisasi.

Pada tahun 2015 pemerintah menambah Alokasi dana desa lebih besar melalui APBN-P untuk memperkuat pembangunan desa. Pengalokasian Dana Desa tersebut dinamakan Dana Desa (DD). Dana Desa dilakukan dengan menggunakan alokasi yang dibagi secara merata dan alokasi yang dibagi berdasarkan jumlah penduduk, luas wilayah, angka kemiskinan, dan tingkat kesulitan geografis. Alokasi Dana Desa bersumber dari APBN yang diperuntukkan bagi desa yang ditransfer melalui APBD Kabupaten/Kota dan digunakan untuk membiayai penyelenggaraan pemerintahan, pelaksanaan pembangunan, pembinaan kemasyarakatan, dan pemberdayaan masyarakat. Pada pelaksanaanya Alokasi Dana Desa belum sepenuhnya berjalan efektif.

Penyaluran Dana Desa berdasarkan Peraturan Pemerintah Nomor 60 Tahun 2014 tentang Dana Desa sebagaimana dimaksud dalam pasal 15 dilakukan secara bertahap pada tahun anggaran berjalan dengan ketentuan yaitu pada tahap pertama dicairkan sebesar $40 \%$ pada bulan April, tahap kedua dicairkan sebesar $40 \%$ pada bulan Agustus, dan tahap ketiga dicairkan sebesar $20 \%$ pada bulan Oktober. Pengelolaan Alokasi Dana Desa tersebut masih belum sesuai dengan tujuan Alokasi Dana Desa (ADD). Tujuan dari Alokasi Dana Desa (ADD) adalah untuk membiayai program Pemerintah Desa dalam melaksanakan kegiatan pemerintah dan pemberdayaan masyarakat, sehingga pemerataan pendapatan, kesempatan bekerja dan kesempatan berusaha bagi masyarakat desa dapat ditingkatkan.

\section{Tinjauan Pustaka}

\section{Efektivitas}

Efektivitas berasal dari kata efektif yang mengandung pengertian dicapainya tujuan yang telah ditetapkan. Efektivitas selalu terkait dengan hubungan antara hasil yang diharapkan dengan hasil yang sesungguhnya dicapai. Efektivitas dapat dilihat dari berbagai sudut pandang dan dapat dinilai dengan berbagai cara dan mempunyai kaitan yang erat dengan efisiensi. Widjaya (dalam Masyita, 2016:237) menyatakan efektivitas 
adalah hasil membuat keputusan yang mengarahkan melakukan sesuatu dengan benar, yang membantu memenuhi misi suatu perusahaan atau pencapaian tujuan.

Efektivitas menurut Cahyono (dalam Nasila, 2014:1258) adalah kemampuan dari setiap perangkat kerja manusia maupun bukan manusia dapat melahirkan suatu hasil yang maksimal yang digunakan sesuai dengan tujuan yang diharapkan. Begitu pula dengan Gie (dalam Moeljono dan Kusumo, 2019:64) menyatakan bahwa efektivitas adalah keadaan atau kemampuan suatu kerja yang dilaksanakan oleh manusia untuk memberikan hasil guna yang diharapkan. Dengan kata lain, efektivitas adalah segala sesuatu kegiatan yang dilakukan oleh orang atau organisasi yang bertujuan untuk mencapai sasaran target yang ingin dicapai dalam bentuk hasil yang telah ditentukan sebelumnya.

\section{Pembangunan}

Pada prinsipnya pembangunan merupakan salah satu upaya dalam memanfaatkan sumber daya guna membangun masyarakat secara menyeluruh untuk kesejahteraan rakyat dengan dilakukan secara terencana dan berkelanjutan. Menurut Adisasmita (dalam Herlina, 2017:221) pembangunan desa adalah seluruh kegiatan pembangunan yang berlangsung di desa dan meliputi seluruh aspek kehidupan masyarakat, serta dilaksanakan secara terpadu dengan mengembangkan swadaya gotong royong. Tujuannya adalah untuk meningkatkan kesejahteraan masyarakat desa berdasarkan kemampuan dan potensi sumber daya alam mereka melalui peningkatan kualitas hidup, keterampilan dan prakarsa masyaraktat.

Menurut Todaro (dalam Moeljono dan Kusumo, 2019:65) mendefinisikan bahwa pembangunan adalah suatu proses multidemensi yang meliputi perubahan struktur sosial, sikap masyarakat, lembaga-lembaga nasional, sekaligus peningkatan pertumbuhan ekonomi, pengurangan kesenjangan dan pemberantasan kemiskinan. Begitu pula dengan Suharyanto (dalam Johan, 2015:877) mengartikan pembangunan sebagai proses perubahan dari suatu kondisi tertentu ke kondisi lebih baik. Pembangunan dapat diartikan juga sebagai suatu upaya terkoordinasi untuk menciptakan alternatif yang lebih banyak secara sah kepada setiap warga negara untuk memenuhi dan mencapai aspirasinya yang paling manusiawi.

Mustanir dan Darmiah (dalam Latif dkk, 2019:5) menyatakan bahwa pembangunan diartikan sebagai suatu "proses" pembangunan sebagai proses menggambarkan adanya pengembangan baik meliputi proses pertumbuhan ataupun perubahan dalam kehidupan bersama (organisasi) sosial dan budaya. Berdasarkan pengertian pembangunan, bahwa pembangunan adalah sebuah upaya yang dapat membawa masyarakat mengikuti sebuah proses untuk mencapai kehidupan yang sebelumnya dianggap tidak baik, ataupun kurang baik, menjadi sebuah kondisi yang lebih baik. 
204 | Rio Nardianto, Gili Argenti, Evi Priyanti. Efektivitas Alokasi Dana...

\section{Ciri-Ciri Pembangunan Desa}

Pembangunan desa dengan berbagai masalahnya merupakan pembangunan yang berlangsung menyentuh kepentingan bersama. Dengan demikian desa merupakan titik sentral dari pembangunan nasional Indonesia. Oleh karena itu, pembangunan desa tidak mungkin bisa dilaksanakan oleh satu pihak saja, tetapi harus melalui koordinasi dengan pihak lain baik dengan pemerintah maupun masyarakat secara keseluruhan. Dalam merealisasikan pembangunan desa agar sesuai dengan apa yang diharapkan perlu memperhatikan beberapa pendekatan dengan ciri-ciri khusus yang sekaligus merupakan identitas pembangunan desa itu sendiri. Menurut Kansil (dalam Johan, 2015:879) Ciriciri Pembangunan Desa yaitu:

1. Komprehensif multi sektoral yang meliputi berbagai aspek, baik kesejahteraan maupun aspek keamanan dengan mekanisme dan sistem pelaksanaan yang terpadu antar berbagai kegiatan pemerintah dan masyarakat.

2. Perpaduan sasaran sektoral dengan regional dengan kebutuhan essensial kegiatan masyarakat.

3. Pemerataan dan penyebarluasan pembangunan keseluruhan pedesaan termasuk desa-desa di wilayah kelurahan.

4. Satu kesatuan pola dengan pembangunan nasional dan regional dan daerah pedesaan dan daerah perkotaan serta antara daerah pengembangan wilayah sedang dan kecil.

5. Menggerakan partisipasi, prakaras dan swadaya gotong royong masyarakat serta mendinamisir unsur-unsur kepribadian dengan teknologi tepat waktu.

Jadi di dalam merealisasikan pembangunan desa itu harus meliputi berbagai aspek, jangan dari satu aspek saja, agar pembangunan desa itu dapat sesuai dengan apa yang diinginkan. Pembangunan desa itu harus meliputi berbagai aspek kehidupan dan penghidupan artinya harus melibatkan semua komponen yaitu dari pihak masyarakat dan pemerintah, dan harus langsung secara terus menerus demi tercapainya kebutuhan pada masa sekarang dan masa yang akan datang.

\section{Alokasi Dana Desa (ADD)}

Salah satu pendapatan desa yang diterima oleh desa itu ada di APBDes yaitu berupa Alokasi Dana Desa yang bersumber dari Dana Perimbangan Keuangan Pusat dan Daerah dan ditransferkan melalui kepala urusan keuangan desa. Dengan adanya Alokasi Dana Desa, maka kebutuhan desa akan terpenuhi dalam mengelola pembangunan desa dan kepemerintahannya secara otonom.

Dalam Peraturan Pemerintah Nomor 72 Tahun 2005 pasal 1 ayat 11 disebutkan Alokasi Dan Desa (ADD) adalah dana yang dialokasikan oleh Pemerintah Kabupaten/Kota untuk desa, yang bersumber dari bagian dana perimbangan keuangan pusat dan daerah 
yang diterima oleh Kabupaten/Kota. Menurut Rahman dan Novitasari (2018:89) menyatakan bahwa Alokasi Dana Desa merupakan bagian dari komponen APBDesa yang ditujukan untuk mengharuskan pembangunan yang ada di desa dengan prioritas penggunaan untuk pembangunan dan pemberdayaan masyarakat.

Menurut Moeljono dan Kusumo (2019:65) berpendapat bahwa Alokasi Dana Desa adalah dana yang bersumber dari APBN melalui APBD Kabupaten/Kota, dengan tujuan pemerataan kemampuan keuangan antar desa untuk mendanai kebutuhan desa dalam rangka penyelenggaraan pemerintahan dan pelaksanaan pembangunan serta pelayanan masyarakat. Dapat disimpulkan, Alokasi Dana Desa adalah dana yang dialokasikan oleh pemerintah kabupaten untuk desa yang bersumber dari APBN (dana perimbangan) yang diterima oleh kabupaten setelah dikurangi belanja pegawai.

\section{Metode Penelitian}

Metode yang digunakan dalam penelitian ini adalah metode penelitian deskriptif dengan pendekatan kualititatif. Arikunto (2013:3) istilah "deskriptif" berasal dari istilah bahasa inggris to describe yang berarti memaparkan atau menggambarkan sesuatu hal, misalnya keadaan, kondisi, situasi, peristiwa, kegiatan dan lain-lain. Dengan demikian yang dimaksud dengan penelitian deskriptif adalah penelitian yang dimaksudkan untuk menyelidiki keadaan, kondisi, atau hal lain-lain yang sudah disebutkan, yang hasilnya dipaparkan dalam bentuk laporan penelitian. Menurut Sugiyono (2014:13), penelitian kualitatif adalah penelitian yang berlandaskan pada filsafat postpositivisme, digunakan untuk meneliti pada kondisi obyek yang alamiah, (sebagai lawannya adalah eksperimen) dimana peneliti sebagai instrumen kunci, teknik pengumpulan data dilakukan secara triangulasi (gabungan), analisis data bersifat induktif/kualitatif, dan hasil penelitian kualitatif lebih menekankan makna dari pada generalisasi.

Sumber data yang di gunakan terbagi menjadi 2 sumber data, yaitu sumber data primer dan sekunder. Sumber data primer merupakan sumber data yang langsung memberikan data kepada pengumpul data. Data primer dalam penelitian ini diperoleh dengan cara observasi dan wawancara dengan narasumber. Sedangkan sumber data sekunder merupakan sumber yang tidak langsung memberikan data kepada pengumpul data misalnya berasal dari penelitian terdahulu atau lewat dokumen.

Penentuain informan dilakukan dengan teknik purposive sampling, Sugiyono (2014:126), purposive sampling adalah teknik penentuan sampel dengan pertimbangan tertentu. Kemudian informan adalah orang-orang pada lokasi penelitian yang memberikan informasi tentang situasi dan kondisi yang terjadi. Informan yang bertindak sebagai sumber data dan informasi harus memenuhi syarat, yang akan menjadi informan narasumber (key informan). Peneliti kualitatif sebagai human instrument, berfungsi menetapkan fokus penelitian, memilih informan sebagai sumber data, 
206 | Rio Nardianto, Gili Argenti, Evi Priyanti. Efektivitas Alokasi Dana...

melakukan pengumpulan data, menilai kualitas data, analisis data, menafsirkan data dan membuat kesimpulan atas temuannya. Bila di lihat dari segi cara atau teknik pengumpulan data, maka teknik pengumpulan data dapat dilakukan dengan observasi (pengamatan), wawancara (interview), dan dokumentasi.

Menurut Bogdan (dalam Sugiyono, 2014:332), analisis data kualitatif adalah proses mencari dan menyusun secara sistematis data yang diperoleh dari hasil wawancara, catatan lapangan, dan bahan-bahan lain, sehingga dapat mudah dipahami, dan temuannya dapat diinformasikan kepada orang lain. Analisis data dilakukan dengan mengorganisasikan data, menjabarkannya ke dalam unit-unit, melakukan sintesa, menyusun ke dalam pola, memilih mana yang penting dan yang akan dipelajari, dan membuat kesimpulan yang dapat diceritakan kepada orang lain. Aktivitas dalam analisis data yaitu reduction data (reduksi data), display data (penyajian data), conclution drawing/verification (verifikasi).

\section{Pembahasan}

Dalam pembahasan ini peneliti akan membahas hasil penelitian tentang Efektivitas Alokasi Dana Desa Dalam Meningkatkan Pembanguna Di Desa Pulokalapa Kecamatan Lemahabang Kabupaten Karawang, data yang peneliti dapat lebih banyak berupa tindakan dan kata-kata yang didapat pada saat melalui proses wawancara dan observasi

\section{Tahap Adaptasi Pengelolaan Alokasi Dana Desa}

Adaptasi diartikan dengan tingkat dimana organisasi dapat dan benar-benar tanggap terhadap perubahan internal dan eksternal atau mengacu pada kemampuan manajemen, merasakan perlunya perubahan dalam organisasi. Hal ini menjadi penting sebab adaptasi merupakan salah satu indikator keberhasilan suatu kegiatan, dalam perencanaan keuangan desa, diperlukan rencana tahapan yang strategis. Salah satu yang dapat direncanakan dalam hal tersebut adalah cara mengalokasikan dana desa dengan sebaik-baiknya.

Pada tahap adaptasi pengelolaan Alokasi Dana Desa di Desa Pulokalapa Kecamatan Lemahabang, telah sesuai dengan ketentuan yang berlaku dimana telah diawali dengan pembentukan organisasi pelaksana dan proses perencanaan dilakukan dengan model partisipatif dalam kegiatan Musyawarah Perencanaan Pembangunan Desa (Musrenbangdes). Dalam pelaksanaan Alokasi Dana Desa yang dimaksud dalam perencanaan tersebut terdiri dari BPD, LPMD, dan Masyarakat lainnya, perencanaan alokasi dana desa dilakukan dengan menjaring aspirasi dan kebutuhan masyarakat melalui musyawarah desa. Perencanaan dengan model partisipatif dilakukan melalui musrenbang desa dengan melibatkan seluruh elemen masyarakat mulai dari lembaga masyarakat, tokoh masyarakat dan seluruh masyarakat desa. Musrenbang desa tersebut bertujuan untuk mendorong masyarakat agar turut serta berpartisipasi dalam menyusun 
dan menentukan rencana kegiatan pembangunan di desa. Sehingga rencana kegiatan yang tertuang dalam Daftar Usulan Rencana Kegiatan (DURK) yang dihasilkan adalah gambaran dari harapan dan kebutuhan seluruh masyarakat setempat.

Hasil pengamatan dan informasi yang diperoleh menunjukan bahwa kegiatan musrenbang desa dalam tahapan adaptasi di pulokalapa masih sebatas kepada memenuhi ketentuan dan belum menyentuh kepada esensi yang terkandug dari maksud kegiatan musrenbang desa, terlihat bahwa tingkat partisipasi masyarakat masih sangat rendah, kondisi tersebut ditunjukan dengan sedikitnya jumlah masyarakat yang hadir maupun yang menyampaikan aspirasi/pendapat dalam musrenbang desa dengan kegiatan yang akan dilakukan. Dari 30 responden kalangan masyarakat, sebanyak 18 orang yang menghadiri kegiatan musrembang desa tersebut, tetapi mereka tidak menyampaikan aspirasi/usulan rencana kegiatan. Sedangkan 12 orang lainya tidak hadir. Pada Proses Perencanaan Alokasi Dana Desa diawali dengan rapat perdusun, untuk menyusun rencana kegiatan tersebut harus melibatkan partisipasi seluruh komponen yang ada di desa baik lembaga kemasyarakatan maupun masyarakat umum melalui forum musyawarah tingkat desa. Dapat digambarkan proses perencanaan penggunaan Alokasi Dana Desa (ADD) dalam skema berikut: Alur Perencanaan Penggunaan Alokasi Dana Desa di Desa Pulokalapa. Rapat perdusun rapat kecil-kecilan survey pembentukan TIM pelaksana kegiatan Alokasi Dana Desa masyarakat membuat daftar kebutuhan masyarakat Format RKP Musrenbang Desa evaluasi Penetapatan RKP Desa Penyusunan RPD. Musrenbang Desa adalah forum musyawarah yang membahas usulan-usulan rencana kegiatan pembangunan desa yang berpedoman pada prinsipprinsip perencanaan pembangunan partisipasi masyarakat Desa serta transparansi pemerintah kepada masyarakat. Pada Program kerja pada bidang pelaksanaan Pembangunan Desa Pulokalapa telah disepakati bersama masyarakat, unsur LPMD dan BPD dalam Forum Musrenbang Desa, usulan pembangunan yang diusulkan oleh masyarakat Desa Pulokalapa telah terlaksana dengan rincian anggaran berdasarkan RAB yang disusun oleh Tim Pelaksana Kegiatan (TPK) Alokasi Dana Desa (ADD).

Dapat dianalisis bahwa efektivitas adaptasi perencanaan dalam program dan kegiatan pengelolaan ADD, yang dilakukan oleh Pemerintah Desa Pulokalapa. Namun prosesnya belum optimal. Hal ini terlihat dalam proses, pelaporan dan pertanggungjawaban yang mengalami keterlambatan. Untuk peroses pelaporan realisasi penggunaan $A D D$, belum sesuai dengan jadwal yang ditentukan sehingga dapat menyebabkan proses keterlambatan pencairan dana untuk tahapan berikutnya. Sehingga masyarakat tidak dapat mengevaluasi hasil kerja Pemerintahan Desa, dan pertanggungjawaban, kepada pemerintah daerah yang tidak dilaksanakan tepat waktu dalam meningkatkan pembangunan fisik di Desa Pulokalapa Kecamatan Lemahabang 
208 | Rio Nardianto, Gili Argenti, Evi Priyanti. Efektivitas Alokasi Dana...

Kabupaten Karawang. Berikut alur diagram tahap adaptasi pengelolaan Alokasi Dana Desa.

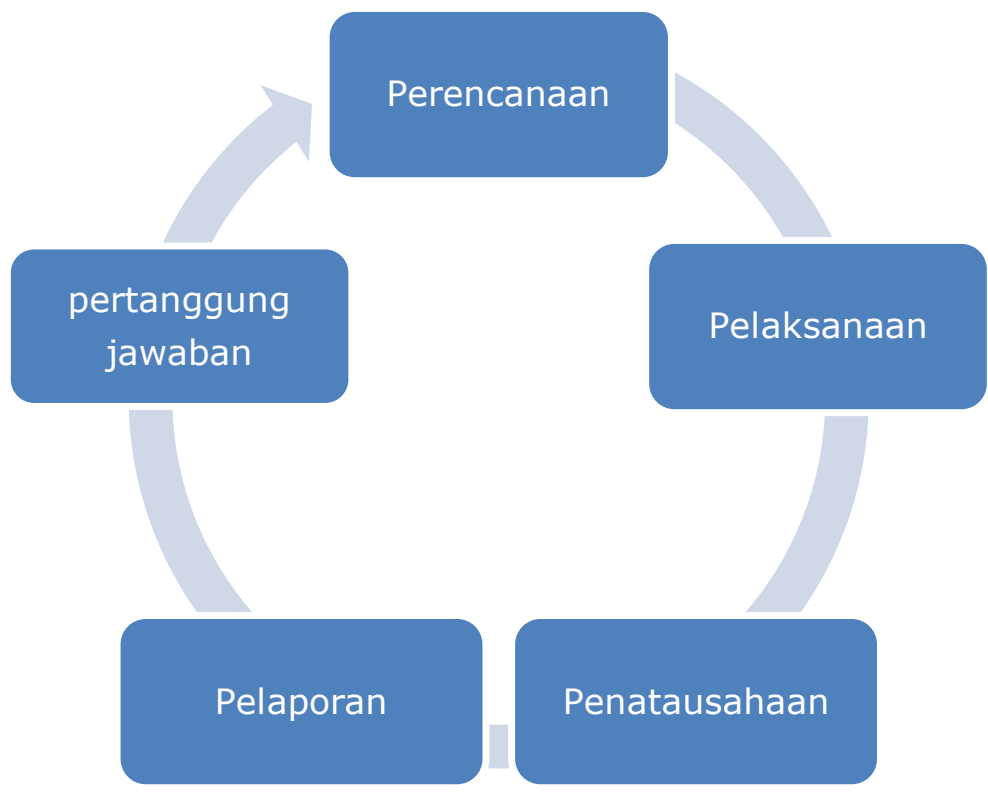

Sumber: Peraturan Bupati Karawang Nomor 14 Tahun 2014 tentang Pengelolaan Keuangan Desa.

\section{Tahap Efisiensi Pengelolaan Alokasi Dana Desa}

Dalam pelaksanaan program bantuan kepada pemerintah desa, setiap tahun Bupati Karawang mengeluarkan surat yang mengatur tentang pelaksanaan suatu program yang dapat membantu Perangkat Desa. Pelakasanaan kegiatan Pengelolaan Alokasi Dana Desa dalam meningkatkan pembangunan fisik, dengan anggaran Alokasi Dana Desa di Desa Pulokalapa didasarkan pada peraturan Bupati Kabupaten Karawang Nomor 43 Tahun 2015 tentang pedoman pengelolaan alokasi dana desa. Alokasi Dana Desa diperuntukan untuk pelaksanaan fisik berupa infrastruktur fasilitas penunjang masyarakat dan pemberdayaan masyarakat dengan ketentuan 30\% (tiga puluh persen) digunakan untuk kegiatan operasional pemerintah desa dan BPD, serta 70\% digunakan untuk kegiatan pemberdayaan masyarakat.

Dapat dianalisis bahwa efektivitas terhadap efisiensi alokasi dana desa di Desa Pulokalapa cenderung terlihat masih kurang efisien, baik dalam penggunaan alokasi dana desa maupun dalam penyaluran anggarannya. Tetapi bisa kita lihat diatas bahwasanya pembangunan yang telah terbentuk, dengan royalitanya kepala desa pembangunan yang terhambat dengan adanya masalah keuangan kepala desa berbesar hati meneluarkan uang pribadinya demi keberlangsungan pembangunan di Desa Pulokalapa. Berikut tabel peruntukan Alokasi Dana Desa: 


\begin{tabular}{|c|c|c|}
\hline No & $\begin{array}{c}\text { Tahap } \\
\text { Kegiatan }\end{array}$ & Indikator \\
\hline 1 & Perencanaan & $\begin{array}{l}\text { - Sekertaris Desa menyusun Rancangan Peraturan } \\
\text { Desa tentang APBDesa berdasarkan RKPdesa } \\
\text { tahun berkenaan. } \\
\text { - Rancangan Peraturan Desa tentang APBDesa } \\
\text { disepakati paling lambat bulan Oktober tahun } \\
\text { berjalan. } \\
\text { - Rancangan Peraturann Desa tentang APBDesa yang } \\
\text { telah disepakati bersama disampaikan oleh Kepala } \\
\text { Desa kepada Bupati melalui Camat paling lambat } 3 \\
\text { (tiga) hari sejak disepakati untuk dievaluasi. } \\
\end{array}$ \\
\hline 2 & Pelaksanaan & $\begin{array}{l}\text { - Semua penerimaan dan pengeluaran desa } \\
\text { dilaksankan melalui rekening desa dengan didukung } \\
\text { oleh bukti yang lengkap dan sah. } \\
\text { - Pelaksanaan kegiatan mengajukan Rencana } \\
\text { Anggaran Biaya yang diverivikasi oleh Sekertaris } \\
\text { Desa. } \\
\text { - Berdasarkan Rencana Anggaran Biaya, pelaksana } \\
\text { kegiatan mengajukan Surat Permintaan Pembayaran } \\
\text { (SPP). }\end{array}$ \\
\hline 3 & Penatausahaan & $\begin{array}{l}\text { - Bendahara Desa melakukan pencatatan setiap } \\
\text { pengeluaran dan penerimaan dan melakukan tutup } \\
\text { buku setiap akhir bulan secara tertib. } \\
\text { - Bendahara Desa mempertanggungjawabkan uang } \\
\text { melalui laporan pertanggungjawaban yang } \\
\text { disampaikan setiap bulan kepada Kepala Desa paling } \\
\text { lambat tanggal } 10 \text { bulan berikutnya. }\end{array}$ \\
\hline 4 & Pelaporan & $\begin{array}{l}\text { - Sekertaris Desa menyusun laporan semester } \\
\text { pertama dan Kepala Desa menyampaikan kepada } \\
\text { Bupati/Walikota pada akhir bulan Ju ni tahun } \\
\text { berjalan. } \\
\text { - Sekertaris Desa menyusun laporan semester akhir } \\
\text { tahun dan Kepala Desa menyampaikan kepada } \\
\text { Bupati/Walikota paling lambat bulan Januari tahun } \\
\text { berikutnya. }\end{array}$ \\
\hline 5 & $\begin{array}{c}\text { Pertanggung- } \\
\text { jawaban }\end{array}$ & $\begin{array}{l}\text { - Sekertaris Desa menyusun laporan } \\
\text { pertanggungjawaban } \\
\text { - Kepala Desa menyampaikan kepada Bupati/Walikota } \\
\text { setiap akhir rahun melalui Camat paling lambat } 1 \\
\text { (satu) bulan setelah akhir tahun anggaran } \\
\text { - Laporan realisasi dan laporan pertanggungjawaban } \\
\text { realisasi pelaksanaan APBDesa diinformasikan ke } \\
\text { masyarakat. }\end{array}$ \\
\hline
\end{tabular}

Sumber: Peraturan Menteri Dalam Negeri Nomor 113 Tahun 2014 Tentang Pengelolaan Keuangan Desa

\section{Tahap Pengembangan Pengelolaan Alokasi Dana Desa}

Pengembangan penatausahaan keuangan desa adalah seluruh kegiatan keuangan yang dilakukan oleh pemerintahan desa yakni bendahara desa terdiri dari penatausahaan penerimaan dan penatausahaan pengeluaran serta pelaporan pertanggungjawabannya kepada pihak yang berkepentingan. Kepala Desa memegang kuasa tertinggi dalam pengelolaan keuangan desa karena jabatannya sebagai kepala 
210 | Rio Nardianto, Gili Argenti, Evi Priyanti. Efektivitas Alokasi Dana...

pemerintahan di tingkat desa. Dalam pelaksanaannya, kepala desa dibantu oleh Pelaksana Teknis Pengelolaan Keuangan Desa (PTPKD) yang merupakan perangkat desa yang ditunjuk kepala desa, PTPKD atau Pelaksana Teknis Pengelolaan Keuangan Desa merupakan unsur perangkat desa yang membantu Kepala Desa untuk melaksanakan pengelolaan keuangan desa. Bendahara dijabat oleh staf pada urusan Keuangan. Bendahara mempunyai tugas menerima, menyimpan, menyetorkan atau membayar, menatausahakan, dan mempertanggungjawabkan penerimaan pendapatan desa dan pengeluaran pendapatan desa dalam rangka pelaksanaan APBDesa.

Bendahara Desa wajib melakukan pencatatan setiap penerimaan dan pengeluaran serta melakukan tutup buku setiap akhir bulan secara tertib dan Bendahara Desa wajib dapat mempertanggung jawabkan keuangan melalui laporan pertanggung jawaban. Laporan pertanggungjawaban disampaikan setiap bulan kepada Kepala Desa paling lambat tanggal 3 bulan berikutnya. Dokumen yang digunakan oleh bendahara dalam melakukan penatausahaan penerimaan dan pengeluaran antara lain, buku kas umum, buku kas pembantu pajak dan buku bank. Buku kas umum digunakan untuk mencatat seluruh bukti transaksi keuangan desa. Buku kas pembantu pajak digunakan untuk mencatat bukti transaksi terkait dengan pemungutan maupun penyetoran pajak oleh bendahara desa. Dapat dianalisis dalam melaksanakan penatausahaan yang dilakukan oleh Pemerintah Desa Pulokalapa dalam hal ini Pelaksana Tugas Pengelolaan Keuangan Desa (PTPKD) sudah sesuai dengan Peraturan yang ada diPeraturan Bupati Karawang Nomor 43 tahun 2015 Tentang Pengelolaan Keuangan Desa dan bahwa dengan adanya Penatausahaan yang dilakukan Bendahara Desa berupa Buku Kas Umum, Buku Kas, Pembantu Pajak dan Buku Bank sangat mempermudahkan BPD dan masyarakat untuk mengetahui ada atau tidak adanya penyelewengan dari dana yang begitu besar dipegang atau dikelola pemerintah desa.

\section{Tahap Kepuasan Pengelolaan Alokasi Dana Desa}

Tingkat kepuasan dalam tahap penyelesaian penyusunan pertanggungjawaban Pengelolaan Alokasi Dana Desa dalam meningkatkan pembangunan fisik di Desa Pulokalapa Kecamatan Lemahabang, dalam tahapan kepuasan ini tidak efektif, dimana penyusunan Laporan Pertanggung Jawaban (LPJ) tidak disusun oleh pemerintah desa khususnya sekretaris desa, namun penyusunan laporan pertanggung jawaban ini disusun dan diselesaikan oleh pihak ketiga yang bukan berasal dari pihak pemerintah atau lembaga Desa Pulokalapa serta tidak ada transparansi kepada masyarakat, sehingga masyarakat tidak mengetahui anggaran yang telah diterima oleh pemerintah desa, karena kurangnya tanggung jawab mereka sebagai tim evaluasi dari setiap kegiatan yang dilakukan dalam Pengelolaan Alokasi Dana Desa. Dan hasil penelitian menunjukan bahwa, laporan pertanggungjawaban Desa Pulokalapa memang tidak 
disusun oleh pemerintah desa selaku penanggung jawab pelaksana kegiatan, melainkan disusun oleh pihak lainnya.

Pembuatan pelaporan pertanggungjawaban ini dimaksudkan agar setiap kegiatan yang dilakukan oleh pemerintah desa berdasarkan aturan yang ditetapkan dan tidak menyimpang. Hal ini merupakan wujud pertanggungjawaban terhadap pemerintan desa kepada masyarakat. Namun, realitas yang terjadi di Desa Pulokalapa bahwa kegiatan laporan pertanggungjawaban tidak direncanakan dan dilaksanakan dengan baik. Dapat dianalisis bahwa laporan pertanggungjawaban Desa Pulokalapa tidak disusun oleh pemerintah desa selaku penanggung jawab pelaksana kegiatan, melainkan disusun oleh pihak lain. Pertanggungjawaban Alokasi Dana Desa terintegrasi dengan pertanggungjawaban APBDesa yang harus disampaikan kepada Bupati. Berikut alur diagram tahap penyusunan pertanggungjawaban pengelolaan Alokasi Dana Desa.

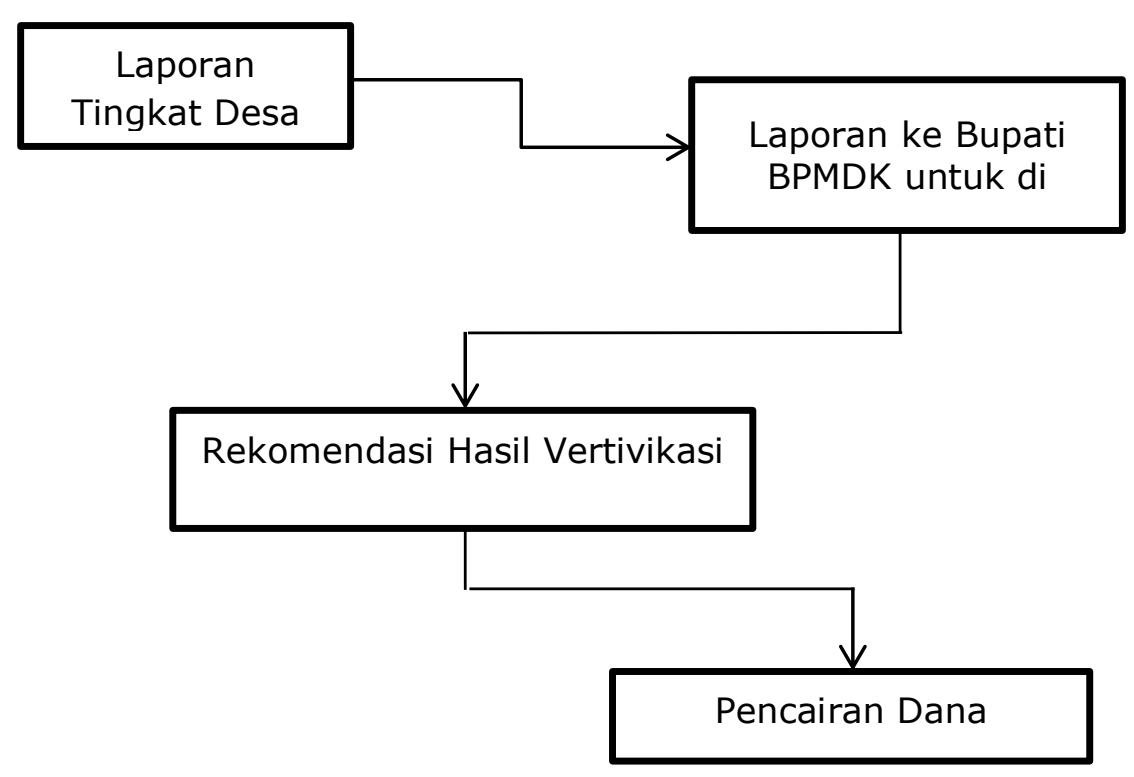

\section{Kesimpulan Dan Saran}

Berdasarkan uraian pada hasil penelitian dan pembahasan dapat ditarik kesimpulan bahwa Efektivitas Alokasi Dana Desa Dalam Meningkatkan Pembangunan Di Desa Pulokalapa Kecamatan Lemahabang Kabupaten Karawang dapat dinilai dari empat dimensi yaitu, adaptasi, efisiensi, pengembangan, dan kepuasan.

1. Dimensi adaptasi, berdasarkan hasil penelitian yang dilakukan terkait dengan dimensi adaptasi bisa kita artiakn sebagai penyesuaian perencanaan pembangunan desa, di Desa Pulokalapa Kecamatan Lemahabang Kabupaten Karawang dalam pengelolaan alokasi dana desa prosesnya perencanaannya belum optimal. Hal ini terlihat dalam proses pelaporan dan pertanggungjawaban yang mengalami keterlambatan. Untuk peroses pelaporan realisasi penggunaan ADD, belum sesuai dengan jadawal yang telah direncanakan sehingga dapat menyebabkan proses keterlambatan pencairan dana untuk tahapan berikutnya. Sehingga masyarakat 
212 | Rio Nardianto, Gili Argenti, Evi Priyanti. Efektivitas Alokasi Dana...

tidak dapat mengevaluasi hasil kerja Pemerintahan Desa, dan pertanggungjawaban, kepada pemerintah daerah yang tidak dilaksanakan tepat waktu dalam meningkatkan pembangunan fisik di Desa Pulokalapa Kecamatan Lemahabang Kabupaten Karawang.

2. Dimensi Efisiensi, berdasarkan hasil penelitian yang dilakukan terkait dengan dimensi Efisiensi, Desa Pulokalapa Kecamatan Lemahabang Kabupaten Karawang dalam pengelolaan alokasi dana desa Pemerintah Desa Pulokalapa mendapat respon yang positif dalam Pelaksanaan Penggunaan Alokasi Dana Desa, khususnya dalam melaksanakan Pembangunan. Dalam melakukan pembangunan Kepala Desa Pulokalapa selalu ikut berpartisipasi dalam hal memantau proses pembangunan desa sehingga pembangunan menjadi lebih cepat. Namun pembangunan yang dilaksanakan belum merata disetiap dusun karna yang diutamakan dilaksanakannya pembangunan di wilayah pemenagan kepala desa.

3. Dimensi Pengembangan, berdasarkan hasil penelitian yang dilakukan terkait dengan dimensi Pengembangan, Desa Pulokalapa Kecamatan Lemahabang Kabupaten Karawang dalam pengelolaan Alokasi Dana Desa, dalam hal ini Pelaksana Tugas Pengelolaan Keuangan Desa (PTPKD) sudah sesuai dengan Peraturan yang ada di Peraturan Bupati Karawang Nomor 43 tahun 2015 Tentang Pengelolaan Keuangan Desa dan bahwa dengan adanya Penatausahaan yang dilakukan Bendahara Desa berupa Buku Kas Umum, Buku Kas, Pembantu Pajak dan Buku Bank sangat mempermudahkan BPD dan masyarakat untuk mengetahui ada atau tidak adanya penyelewengan dari dana yang begitu besar dipegang atau dikelola pemerintah desa. Namun sdm terkait pengoprasiaan belum mahir dalam pengoprasian komputer akibatnya proses dalam penatausahaan dan pelaporan menjadi terlambat, sehingga pembangunnan yang di ajukan selanjutnya menjadi terlambat dan sulit berkembang untuk memajukan Desa Pulokalapa

4. Dimensi Kepuasan, berdasarkan hasil penelitian yang dilakukan terkait dengan dimensi Kepuasan, Desa Pulokalapa Kecamatan Lemahabang Kabupaten Karawang dalam pengelolaan Alokasi Dana Desa, bahwa dalam proses pelaporan dalam pengelolaan Alokasi Dana Desa oleh Pemerintah Desa Pulokalapa ke BPMDK Kabupaten Karawang masih belum sesuai dengan Peraturan yang telah ditetapkan dimana pemerintah Desa belum mampu untuk melaporkan kegiatan sesuai dengan jadwal waktu yang ditentukan. Terlihat dari belum dirampungkannya Laporan Realisasi Tahap II. Selain itu, Desa Pulokalapa Kecamatan Lemahabang Kabupaten Karawang juga harus memberikan pelayanan yang berkualitas sesuai dengan Peraturan Bupati Undang-Undang Nomor 43 Tahun 2015 tentang Pendoman Pengelolaan Alokasi Dana Desa di Kabupaten Karawang. 


\section{Saran}

Berdasarkan kesimpulan di atas, peneliti mengajukan beberapa saran diantaranya:

1. Sebagai pemerintah Desa Pulokalapa Kecamatan Lemahabang Kabupaten Karawang harus meningkatkan kualitas Sumber Daya Manusia untuk setiap tim pengelola Alokasi Dana Desa. Kemudian perlunya transparasi informasi yang disampaikan kepada masyarakat dalam pengelolaan Alokasi Dana Desa sehingga dapat meningkatkan partisipasi masyarakat dapat mencapai tujuan dari Alokasi Dana Desa.

2. Perlu diperbaiki prosedur pengelolaan Alokasi Dana Desa khusus pada kegiatan penyusunan rencana kegiatan maupun pada pelaksanaanya yaitu dengan dilibatkan masyarakat secara aktif melalui forum musyawarah desa yang dapat memberikan kesempatan kepada seluruh masyarakat desa pulokalapa untuk menyampaikan aspirasi seluruh masyarakat.

3. Untuk memperkuat aspek keuangan desa, pemerintah desa pulokalapa harus konsisten merealisasikan anggaran Alokasi Dana Desa yang sesuai dengan peraturan Undang-Undang yang berlaku, yakni minimal mengalokasikan sebesar $10 \%$ dari total penerimaan dana perimbangan sedangkan untuk meningkatkan kapasitas pemerintah desa secara optimal dalam hal pelatihan pengelolaan keuangan desa, pemerintah desa pulokalapa harus melakukan pembinaan dan pendampingan kepada perangkat desa yang ada di desa pulokalapa.

4. Penulis menyarankan agar pemerintah desa pulokalapa saling bekerja sama dengan pemerintah kecamatan agar dalam menjalankan tugas yang telah ditetapkan dalam pengelolaan Alokasi Dana Desa sehingga tercapainya tujuan yang telah direncanakan, karena jika dilihat dari permasalahan yang terjadi setiap tahunnya tidak jauh berbeda, selain itu konsistensi pemerintah dalam pelaksanaan pengelolaan Alokasi Dana Desa terhadap peraturan tentang Alokasi Dana Desa harus secara tepat dilaksanakan agar permasalahan yang sebelumnya bisa diatasi untuk tahun berikutnya.

\section{DAFTAR PUSTAKA}

\section{Buku-buku}

Arikunto, S. (2013). Prosedur Penelitian: suatu pendekatan praktik. Jakarta: Rineka Cipta.

Sugiyono. (2014). Metode Penelitian Kombinasi (Mixed Methods). Bandung: Alfabet. 
214 | Rio Nardianto, Gili Argenti, Evi Priyanti. Efektivitas Alokasi Dana...

\section{Jurnal}

Herlina, V. (2017). Analisis Partisipasi Masyarakat Dalam Pembangunan Fisik Di Desa Pungut Hilir Kabupaten Kerinci. Jurnal Ipteks Terapan, 11(3), 220-232.

Johan, S. (2015). Peran Kepala Desa Dalam Meningkatkan Pembangunan Fisik Di Desa Long Nawang Kecamatan Kayan Hulu Kabupaten Malinau. Ejournal IImu Pemerintahan, 3 (2), 874-888.

Julianto, A. (2017). Efektivitas Pengelolaan Alokasi Dana Desa (ADD) Di Kecamatan Sembakung Kabupaten Nunukan. Ejournal Pemerintahan Integratif, 5(4), 478487.

Latif, A. dkk. (2019). Partisipasi Masyarakat Dalam Pembangunan Infrastruktur Di Desa Timoreng Panua Kecamatan Panca Rijang Kabupaten Sindereng Rappang. Jurnal MODERAT, 5(1), 1-15.

Masyita, S. (2016). Efektivitas Kinerja Pegawai Dalam Pelayanan Masyarakat Untuk Membuat E-Ktp Pada Kantor Kecamatan Bontoa Kabupaten Maros. Jurnal Ilmiah Bongaya (Manajemen Dan Akutansi), 10(1), 236-249.

Moeljono dan Kusumo, W.K. (2019). Efektivitas Pengelolaan Alokasi Dana Desa. Jurnal IImiah Solusi, 17(3), 61-76.

Nasila, J.W. (2014). Efektivitas Program Daerah Pemberdayaan Masyarakat (PDPM), Studi Tentang Penanggulangan Kemiskinan Dikelurahan Mamboro Kecamatan Palu Utara Kota Palu. Jurnal Academica Fisip Untal, 6(2), 1253-1264.

Rahman, A.Z., dan Novitasari, D. (2018). Kebijakan Pembangunan Desa Melalui Pembangunan Infrastruktur Transportasi Dalam Upaya Pemerataan Pembangunan. Jurnal Manajemen Dan Kebijakan Publik, 3(2), 85-91.

\section{Skripsi}

Agustoni, I. (2019). Analisis Pengelolaan Alokasi Dana Desa (ADD) Untuk Meningkatkan Tata Kelola Pemerintahan Yang Baik Pada Desa Tanjung Atap Dan Tanjung Atap Barat Di Kecamatan Tanjung Batu Kabupaten Ogan Ilir. Skripsi Fakultas Ekonomi Dan Bisnis Universitas Muhammadiyah Palembang. Tidak Diterbitkan.

\section{Peraturan Perundang-undangan}

Peraturan Bupati Karawang Nomor 14 Tahun 2014 Tentang Pengelolaan Keuangan Desa.

Peraturan Bupati Karawang Nomor 43 Tahun 2015 Tentang Pedoman Pengelolaan Alokasi Dana Desa Di Kabupaten Karawang.

Peraturan Menteri Dalam Negeri Nomor 113 Tahun 2014 Tentang Pengelolaan Keuangan Desa.

Peraturan Pemerintah Republik Indonesia Nomor 72 Tahun 2005 Tentang Desa.

Undang-Undang Republik Indonesia Nomor 6 Tahun 2014 Tentang Desa 